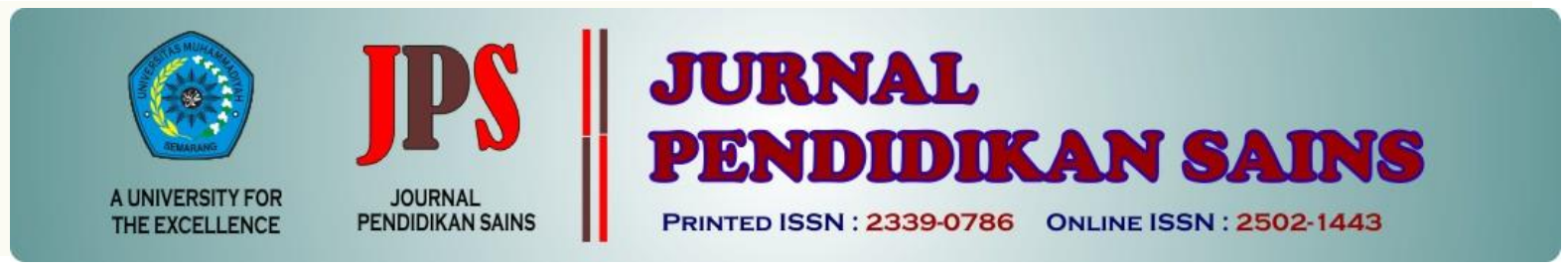

http://jurnal.unimus.ac.id/index.php/JPKIMIA

\title{
PENERAPAN MODEL BOUNDED INQUIRY LAB BERBANTUAN MACROMEDIA FLASH UNTUK MENINGKATKAN HASIL BELAJAR DAN SIKAP ILMIAH SISWA KELAS VIII SMP KRISTEN 2 SALATIGA
}

\author{
Oleh: \\ Iva Apriliana, Risya Pramana Situmorang*, Santoso Sastrodihardjo \\ Program Studi Pendidikan Biologi, Fakultas Biologi \\ Universitas Kristen Satya Wacana, Salatiga, Indonesia.
}

\begin{tabular}{ll}
\hline \multicolumn{2}{l}{ Article history } \\
\hline Submission & $: 2018-12-28$ \\
Revised & $: 2019-02-08$ \\
Accepted & $: 2019-04-01$
\end{tabular}

Keyword:

Kata kunci: bounded inqury lab, macromedia flash, hasil belajar kognitif, sikap ilmiah

\begin{abstract}
This research was classroom action research that implemented of bounded inquiry lab model assisted by macromedia flash to improve learning outcomes and scientific attitudes. This research method used the design model Kemmis and Mc Taggart which in class action research conducted with 2 cycles for one cycle of research there were 4 phases include planning, action, observation and reflection. The results of applying the bounded inquiry lab model assisted by macromedia flash to improve learning outcomes of the largest percentage cycle I, namely the medium category with a percentage score of $52 \%$ and a decrease in value of $4 \%$ from 25 In the second cycle, the average score was $32 \%$, spread in three categories, namely medium, low, decreased and there was also no increased. students' scientific attitudes from cycle I to cycle II students were measured through observation of activities based on aspects of scientific attitudes and student response questionnaires. The average increased that occured from each aspect is $10 \%$, with the average percentage of the overall indicator is $60 \%$.
\end{abstract}

\section{Pendahuluan}

Tujuan pendidikan nasional adalah membentuk manusia Indonesia yang berkualitas dengan memiliki pengetahuan, keterampilan dan sikap. Artinya proses pendidikan yang diharapkan adalah mengarah kepada pembentukan manusia seutuhnya (holistik).Tentu dibutuhkan suatu proses panjang bagi pendidikan untuk mencapai konsep yang ideal. Namun, bukan berarti tujuan

*Corresponding Author:
Nama
: Risya Pramana Situmorang
Lembaga
: Universitas Kristen Satya Wacana
Email

tersebut tidak dapat dicapai. Pendidikan tentu memiliki peran dalam menggali setiap potensi siswa. Tidak hanya berpatok pada kemampuan kognitif tetapi juga memiliki sikap dan keterampilan.

Pencapaian tujuan pendidikan nasional tentu digambarkan dengan capaian dalam kurikulum 2013. Kurikulum 2013 memiliki tujuan yaitu menghasilkan manusia Indonesia yang produktif, kreatif dan sikap unggul. 
Mulyasa (2015) menjelaskan bahwa pentingnya pembentukan sikap terhadap kompetensi dalam kurikulum dan karakter siswa melalui proses pembelajaran. Oleh karena itu, penting bagi guru untuk merancang pembelajaran yang berorientasi pada pengintegrasian antara pengetahuan kognitif dan sikap. Pembelajaran sains merupakan salah satu mata pelajaran di tingkat sekolah menengah yang dapat memberikan pengalaman belajar tentang fenomena alam.

$$
\text { Pendekatan saintifik dalam }
$$
pembelajaran sains meliputi: aspek sikap, produk dan proses. Namun selama ini tujuan pembelajaran sains masih berorientasi pada produk sajasehingga kurang membentuk kemampuan siswa secara holistik. Candra (2007) menjelaskan bahwa ciri utama pembelajaran sains yaitu melibatkan siswa dalam kegiatan ilmiah sehingga dapat mengembangkan sikap ilmiah. Sikap ilmiah merupakan sikap untuk melakukan kegiatan dan sikap ini harus dimiliki pada seorang ilmuan ketika menghadapi persoalan-persoalan ilmiah. (Muchlas, 2011). Sejalan dengan Muchlas, Tursinawati (2013) juga menegaskan bahwa sikap ilmiah merupakan sikap seperti ilmuwan ketika melakukan kegiatan praktikum. kecenderungan seseorang dalam bertindak atau berperilaku dalam memecahkan masalah secara sistematis melalui metode ilmiah. Dengan demikian, sikap ilmiah membentuk siswa untuk belajar dengan pola ilmuwan melalui langkahlangkah yang sistematis dan ilmiah.

Berdasarkan hasil observasi dan wawancara guru IPA kelas VII di SMP Kristen 2, pada saat pembelajaran berlangsung, terlihat siswa dominan kurang merespon pertanyaan dari guru mengenai materi yang sudah dipelajari pada pertemuan sebelumnya. Siswa juga kurang antusias dalam mengikuti pelajaran IPA dan banyak bermain dengan teman sebangku saat guru menjelaskan materi. Ketika berdiskusi hanya siswa-siswa tertentu saja yang berpartisipasi aktif dalam kelompok. Hal ini menunjukkan bahwa aspek dalam sikap ilmiah semisal berpikir kritis, rasa ingin tahu, dan kerjasama masih jauh dari yang diharapkan. Aktivitas siswa yang aktif akan menunjukkan sikap ilmiah yang tinggi pula.

Jika ditinjau dari kemampuan kognitif siswa, berdasarkan ulangan harian materi biologi kelas VIII B SMP Kristen 2 Salatiga, memiliki persentase ketuntasan yang cukup rendah pada materi " struktur dan fungsi tumbuhan”. Menurut guru, materi tersebut hanya bersifat informative saja, dan guru hanya menjelaskan materi agar siswa memiliki pemahaman secara teoritik. Persentase ketuntasan siswa pada materi struktur dan fungsi tumbuhan adalah 75. Pada tahun ajaran 2018-2019 sekolah SMP 2 Kristen Salatiga dibagi menjadi tiga kelas IPA pada kelas VIIIA, VIIIB, dan VIIIC. Dari ketiga kelas tersebut dibedakan menjadi satu kelas unggulan yaitu kelas VIIIA dan dua kelas biasa yaitu kelas VIIIB dan VIIIC. Rata-rata kelas unggulan nilai IPA diatas KKM yang telah ditentukan, akan tetapi di kelas biasa banyak nilai siswa dibawah KKM. Sebagian besar siswa yang masuk kelas unggulan merupakan siswa yang memiliki minat cukup tinggi dalam bidang IPA, sedangkan untuk kelas biasa siswa lebih berminat dalam bidang olahraga, sehingga guru kelas biasa dituntut untuk sangat kreatif dalam pembelajaran didalam kelas. Sarana dan prasarana peralatan laboratorium disekolah tersebut cukup baik, walaupun tidak semua bisa menggunakannya karena keterbatasan waktu saat pembelajaran. SMP Kristen 2 Salatiga belum menerapkan sikap ilmiah secara spesifik karena dalam sekolah terdapat empat pilar sikap ilmiah meliputi disiplin, tanggungjawab, santun dan jujur walaupun tidak semua siswa dapat melakukan empat pilar sikap ilmiah yang sudah diterapkan tetap ada prosesnya.

Berdasarkan permasalahan yang ditemukan, diperlukan pembelajaran yang dapat meningkatkan aktivitas siswa sehingga dapat memberdayakan sikap ilmiah dan hasil belajar kognitif siswa. Salah satu model pembelajaran yang dapat memberdayakan sikap ilmiah siswa adalah model Bounded Inquiry Lab. Model inquiry merupakkan salah satu model pembelajaran yang didalam pelaksanaannya mendorong peserta didik untuk menghubungkan antara pengetahuan yang dimiliki dengan mengaplikasikan secara nyata dalam kehidupan sehari-hari, sehingga melalui ini dapat tercipta pola berfikir mandiri dan menemukan suatu konsep dari mengaplikasikannya secara nyata dan proses pengetahuan itu semakin berkembang (Hermita, 2016; Syafa, 2014). Proses cara berfikir secara ilmiah yang dapat memacu peserta didik untuk belajar mandiri adalah dengan melakukan kegiatan praktikum.

Model bounded inquiry lab melatih kemampuan siswa dalam merancangkan dan mengadakan kegiatan praktikum tanpa banyak intervensi dari guru berdasarkan kegiatan prelab. Ciri model bounded inquiry lab adalah saat 
melakukan kegiatan praktikum guru bertanya kepada peserta didik dan pertanyaan guru tidak mengarah secara langsung pada prosedur dari praktikum itu sendiri kemudian pre-lab pada model bounded inquiry lab lebih menekankan pada kegiatan non-ekperimental contohnya keselamatan kerja dan keamanan penggunaan alat laboratorium.

Pelaksanaan model bounded inquiry lab yaitu observasi yang mengarah pada pemberian masalah dan melakukan diskusi lebih lanjut disertai dengan arahan keselamatan kerja, kemudian pembentukan komponen permasalahan-permasalahan yang kecil, mengumpulkan data yang bersangkutan dan mengaitkan hubungan analisis grafik, gambar maupun tabel, mengkomunikasikan hasil temuan kepada kelompok lain dan mengaitkan hasil temuan untuk di aplikasikan dalam kehidupan sehari-hari (Handayani, 2016). Kelebihan bounded inquiry lab adalah mampu melatih kemandirian peserta didik dan tetap memperhatikan keselamatan kerja dan penggunaan perlindungan peralatan laboratorium melalui kegiatan pre-lab, sehingga kedua unsur itu terpenuhi pembalajaran yang dilakukan akan lebih bermakna dan mampu meningkatkan pemahaman peserta didik. Sedangkan kekurangan dari model bounded inquiry lab adalah dalam pelaksaannya tidaklah mudah perlu adannya usaha yang lebih (Sanjaya, 2017).

Meskipun model bounded inquiry lab dapat mendukung proses praktikum dalam IPA, tidak berarti pembelajaran dapat berjalan dengan maksimal. Dibutuhkan bantuan berupa media pembelajaran dalam menunjang pembelajaran IPA. Apalagi di ruang-ruang kelas di SMP Kristen 2 Salatiga sudah difasilitasi dengan perangkat proyektor. Tentu dapat dimanfaatkan melalui penyajian materi IPA sebagai pendukung aspek konten dalam sains. Media pembelajaran yang digunakan untuk memfasilitasi siswa untuk memahami konsep dan fenomena alam secara menarik salah satunya adalah dengan menggunakan media animasi.

Media animasi dapat dirancang menggunakan aplikasi macromedia flash. Penggunaan media animasi dapat menyajikan materi sains secara visual dan audiovisual sehingga siswa dapat berpikir konkret. Aplikasi macromedia flash menyediakan berbagai fitur yang mudah untukdigunakan dalam pengajaran. Namun macromedia flash juga memiliki kekurangan yaitu membutuhkan pemahaman dan keterampilan khusus bagi pengguna dalam merancang dan mengkreasikan penyajian materi (Arsyad, 2004).

Kemampuan siswa dalam aspek kognitif akan membantu pula siswa dalam mengaitkan konsep dan fakta sains dalam kegiatan praktikum melalui model bounded inquiry lab. Kemampuan kognitif yang berbeda-beda tentu menjadi pengelolaan utamadalam penerapan bounded inquiry lab. Model inidapat melibatkan seluruh kemampuan siswa untuk mencari dan menyelidiki suatu permasalah untuk mendapatkan konsep baru. Bahkan dengan bantuan macromedia flash akan lebih mengoptimalkan kemampuan siswa dalam kognitif maupun membangun sikap ilmiah siswa. Berdasarkan latar belakang masalah tersebut peneliti tertarik untuk melakukan penelitian dengan judul "Penerapan Model Bounded Inquiry Lab Berbantuan Macromedia flash untuk Meningkatkan Hasil Belajar dan Sikap Ilmiah".

\section{Metode Penelitian}

Jenis penelitian ini adalah Penelitian Tindakan Kelas (PTK).. Penelitian Tindakan kelas dilakukan dengan 2 siklus, satu siklus penelitian terdapat 4 tahapan menurut Kemmis dan Mc Taggart menyatakan prosedur Penelitian Tindakkan Kelas yang dilaksanakan dengan 4 tahapan yaitu planning (perencanaan), action (tindakan), observation (pengamatan), reflection (refleksi) (Daryanto, 2011). Penelitian Ini menggunakan desain penelitian tindakan kelas model Kemmis dan Mc Taggart (Arikunto, 2006).

Waktu dan Tempat Penelitian

Penelitian Tindakan Kelas ini akan dilaksanakan di kelas VIII SMP Kristen 2 Salatiga, yang beralamat di Jalan Jendral Sudirman No. 111B, Argomulyo, Kota Salatiga. Pelaksanaan penelitian ini pada bulan Oktober sampai Desember 2018 atau semester 1 tahun ajaran 2018/2019.

Subjek Penelitian

Subjek penelitian dalam PTK ini adalah siswa kelas VIIIB SMP Kristen 2 Salatiga yang berjumlah 25 siswa dengan 10 siswa laki-laki dan 15 siswa perempuan.

Prosedur Penelitian

Penelitian Tindakan kelas dilakukan dengan 2 siklus, satu siklus penelitian terdapat 4 tahapan menurut Kemmis dan Mc Taggart 
menyatakan prosedur Penelitian Tindakkan Kelas yang dilaksanakan dengan 4 tahapan yaitu planning (perencanaan), action (tindakan), observation (pengamatan), reflection (refleksi) (Daryanto, 2011). Penelitian Ini menggunakan desain penelitian tindakan kelas model Kemmis dan Mc Taggart (Arikunto, 2006).

Pada tahap perencanaan kegiatan yang dilakukan sebelum melakukan penelitian yaitu: 1) merancang perangkat pembelajaran yaitu silabus dan RPP, 2) merancang lembar observasi siswa yang meliputi sikap ilmiah dan keterlaksanaan model pembelajaran, 3) menyiapkan macromedia flash yang berisi materi pembelajaran struktur dan fungsi tumbuhan, 4) instrumen evaluasi siswa pretest dan posttes siswa selama pembelajaran struktur dan fungsi tumbuhan, 5) instrumen sikap ilmiah dengan indikator sikap ingin tahu, sikap objektif, sikap penemuan dan kreativitas, dan sikap berpikir terbuka dan kerjasama (Adaptasi Martiningsih et al, 2018), 6) persiapan alat dan bahan yang dibutuhkan dalam kegiatan praktikum.

Pelaksanaan tindakan penelitian dilakukan dengan melakukan pembelajaran materi gerak pada tumbuhan sesuai dengan RPP yang sudah disiapkan dengan menggunakan model bounded inquiry lab berbantuan macromedia flash. Bentuk pelaksanaan RPP dijelaskan secara umum sebagai berikut: 1) guru melaksanakan kegiatan yang sudah direncanakan, 2) siswa melakukan kegiatan pembelajaran menggunakan model bounded inquiry lab berbantuan macromedia flash, 3) siswa secara aktif mengikuti kegiatan pembelajaran yang menggunakan model bounded inquiry lab berbantuan macromedia flash.

Observasi dilakukan pada siswa dengan menggunakan lembar observasi siswa. Observasi siswa merupakan kegiatan pengamatan terhadap proses tindakan dalam penelitian. Observasi siswa dilakukan untuk mengetahui bagaimana aktifitas siswa selama proses pembelajaran berlangsung dengan menggunakan model bounded inquiry lab berbantuan macromedia flash.

Refleksi merupakan aktivitas untuk melihat hasil pembelajaran baik hasil pembelajaran secara kognitif dan sikap ilmiah siswa serta kekurangan pada proses pembelajaran yang sudah dilakukan dengan menggunakan model bounded inquiry lab berbantuan macromedia flash. Hasil refleksi ini nanti yang digunakan sebagai acuan untuk melanjutkan atau tidak ke siklus berikutnya.

\section{Teknik Analisis Data}

Data yang dianalisis adalah data hasil observasi siswa, hasil wawancara, angket sikap ilmiah dan hasil evaluasi siswa. Analisis sikap ilmiah dan keterlaksanaan model bounded inquiry lab berbantuan macromedia flash dilakukan melalui teknik nontes yaitu observasi dan angket. Pelaksanaan model bounded inquiry lab berbantuan macromedia flash dinilai terlaksana atau tidak terlaksana dapat dilihat dari setiap butir kisi-kisi lembar observasi.

Data kuantitatif ini di analisis menggunakan rumus persamaan presentase keterlaksanaan model gain score sebagai berikut :

$$
P=\frac{f}{N} \times 100 \%
$$

Keterangan :

$\mathrm{P}=$ Nilai yang dinyatakan dengan presentase

$\mathrm{F}=$ Frekuensi yang sedang dicapai

presentasenya

$\mathrm{N}=$ Jumlah frekuensi

Untuk mengetahui kriteria hasil data instrumen penelitian yang dilakukan maka data yang mula-mula berupa skor di ubah menjadi data kualitatif (data interval) dengan skala lima. Acuan pengubah skor menjadi skala lima tersebut sebagai berikut (Azwar, 1999).

Tabel 1. Konversi Skor Menjadi Nilai Skala

\begin{tabular}{cll}
\multicolumn{2}{c}{ Lima } & \\
\hline Nilai & Interval Skor & Kategori \\
\hline A & $\mathrm{M}+1,5 \mathrm{~S}<\mathrm{X}$ & Sangat baik \\
B & $\mathrm{M}+0,5 \mathrm{~S}<\mathrm{X} \leq \mathrm{M}+1,5 \mathrm{~S}$ & Baik \\
$\mathrm{C}$ & $\mathrm{M}-0,5 \mathrm{~S}<\mathrm{X} \leq \mathrm{M}+0,5 \mathrm{~S}$ & Cukup \\
$\mathrm{D}$ & $\mathrm{M}-1,5 \mathrm{~S}<\mathrm{X} \leq \mathrm{M}-0,5 \mathrm{~S}$ & Kurang \\
$\mathrm{E}$ & $\mathrm{X} \leq \mathrm{M}-1,5 \mathrm{~S}$ & Sangat kurang \\
\hline
\end{tabular}

Keterangan :

$\mathrm{M}=$ Mean (rata-rata)

$\mathrm{M}=\frac{1}{2}($ skor maksimal ideal + skor minimal ideal $)$

$\mathrm{S}=$ Standar deviasi

$\mathrm{S}=\frac{1}{6}($ skor maksimal idal - skor minimal ideal $)$

$\mathrm{X}=$ Skor aktual

Indikator Keberhasilan

Siklus pada PTK ini akan dilakukan secara berulang sampai permasalahan dianggap sudah berhasil diselesaikan. Indikator 
keberhasilan yang menunjukan keberhasilan yang menunjukkan keberhasilan dari siklus tersebut sebagai berikut : terjadi peningkatan hasil belajar kognitif siswa yang memperoleh nilai diatas KKM sebanyak $70 \%$, terjadi peningkatan sikap ilmiah peserta didik setelah pembelajaran dengan model bounded inquiry lab berbantuan macromedia flash dengan peningkatan sikap ilmiah sebanyak $80 \%$ siswa memperoleh nilai yang baik, Keterlaksanaan penerapan model bounded inquiry lab berbantuan macromedia flash dalam pembelajaran sesuai dengan rancangan proses pembelajaran yang sudah disusun dan terlaksana.

\section{Hasil Penelitian dan Pembahasan}

Penelitian ini menggunakan jenis penelitian tindakan kelas (PTK) melalui penerapan model bounded inquiry lab berbantuan macromedia flash untuk meningkatkan hasil belajar dan sikap ilmiah siswa kelas VIII SMP Kristen 2 Salatiga pada materi struktur dan fungsi jaringan tumbuhan. Penelitian tindakan kelas dilakukan dengan 2 siklus untuk satu siklus penelitian terdapat 4 tahapan meliputi perencanaan, tindakan, pengamatan dan refleksi. Hasil penelitian secara keseluruhan menunjukkan penurunan pada hasil belajar dan mengalami peningkatan pada sikap ilmiah siswa yang diterapkan dari siklus pertama dan siklus kedua dengan jumlah pertemuan yang dilakukan sebanyak dua kali setiap pertemuan. Pada akhir siklus kedua diperoleh keberhasilan pencapaian sikap ilmiah namun hasil belajar kognitif masih ditemukan penurunan hasil. Hasil penelitian setiap siklus dijabarkan sebagai berikut.

\section{Siklus I}

Tahap perencanaan dilakukan sebelum melakukan penelitian meliputi merancang perangkat pembelajaran yaitu 1) merancang silabus dan RPP, 2) merancang lembar observasi siswa yang meliputi sikap ilmiah dan keterlaksaan model pembelajaran, 3) menyiapkan macromedia flash yang berisi materi pembelajaran struktur dan fungsi tumbuhan, 4) menyiapkan alat evaluasi siswa pre test dan post test siswa selama pembelajaran struktur dan fungsi tumbuhan, 5) menyiapkan alat dan bahan yang digunakan untuk praktikum.

Tahap tindakan dan observasi penelitan tindakan kelas siklus I dilakukan dengah 2 kali pertemuan. Pelaksanaan tindakan kelas (PTK) pada siklus I dijelaskan sebagai berikut: pertemuan pertama guru memberikan pretes untuk mengukur kemampuan awal hasil belajar siswa. Kegiatan awal pembelajaran guru membuka pembelajaran dengan memberikan apersepsi melalui gambar mengenai struktur tumbuhan, guru juga memberikan pertanyaan kepada siswa untuk melihat pemahaman awal siswa. Kemudian guru menyampaikan tujuan pembelajaran yang akan dicapai siswa, sebelum memasuki kegiatan inti pembelajaran.

Kegiatan inti guru memulai pembelajaran dengan menyajikan materi menggunakan macromedia flash. Penyajian materi dalam macromedia flash masih dalam lingkup gambar-gambar mengenai pengelompokan tumbuhan yang meliputi kelompok tumbuhan tidak berpembuluh, tumbuhan berpembuluh dan tumbuhan berbiji. Materi yang disampaikan pada siklus I disampaikan secara interaktif melalui kegiatan tanya jawab dan diskusi melalui penyajian macromedia flash.

Selanjutnya guru membentuk siswa menjadi 4 kelompok untuk melakukan kegiatan praktikum di laboratorium. Guru membagikan lembar kerja siswa mengenai kegiatan identifikasi organ penyusun tumbuhan beserta fungsinya. Guru mendampingi dan membimbing masing-masing kelompok dalam mengerjakan praktikum. Siswa berdiskusi dan melakukan praktikum secara berkelompok untuk mencari dan mengidentifikasi organ penyusun tumbuhan beserta fungsinya yang meliputi: mengamati dan mendeskripsikan ciriciri umum dari akar, batang dan daun dari tumbuhan bayam kemudian langkah berikutnya mengamati jahe, kentang, wortel, singkong dan kaktus untuk mengidentifikasi masing-masing tumbuhan apakah masuk batang, akar atau daun dan untuk yang terakhir pada tahap praktikum mengamati tumbuhan kaktus, mengidentifikasi apakah tanaman kaktus memiliki daun dan mengidentifikasi dimana letak fotosintesis pada tumbuhan kaktus. Setelah melakukan pengamatan pada lembar kerja siswa juga terdapat pertanyaan-pertanyaan yang harus didiskusikan siswa melalui kegiatan berkelompok tersebut.

Pada pertemuan kedua kegiatan awal yang dilakukan guru adalah mengaitkan materi yang sudah dipelajari pada pertemuan sebelumnya dengan materi struktur dan fungsi organ tumbuhan. Pada pertemuan ini siswa mempresentasikan hasil kerja kelompok yang telah dilakukan berdasarkan hasil praktikum 
pada pertemuan sebelumnya. Kegiatan presentasi dilakukan setiap kelompok secara bergantian dan diakhiri dengan proses tanya jawab. Setiap kelompok memberikan respon terhadap pertanyaan yang diberikan dan membuat catatan berdasarkan hasil diskusi. Guru berperan sebagai fasilitator dan memberikan konfirmasi pada setiap konsep materi yang dipresentasikan dan hasil tanya jawab siswa. Selanjutnya guru memberi pendalaman materi menggunakan macromedia flash yang sudah dirancang dengan memuat materi struktur dan fungsi bunga, buah, dan biji tumbuhan. Diakhir pembelajaran materi struktur dan fungsi akar, batang, daun, bunga, buah dan biji selanjutnya siswa diberikan post test untuk mengetahui hasil belajar kognitif siswa diakhir siklus I.

Refleksi pada siklus I merupakan tahapan untuk mengukur dan menganalisis peningkatan hasil pembelajaran kognitif dan sikap ilmiah siswa. Selain itu, guru dan kolaborator berdiskusi untuk mengevaluasi proses pengajaran yang dilakukan selama siklus I. Perbaikan dalam proses pengajaran dari implementasi model bounded inquiry lab berbantuan macromedia flash dilakukan untuk memodifikasi penyajian macromedia flash dan aktivitas praktikum di laboratorium.

Pada siklus 1 diperoleh hasil belajar kognitif siswa dengan persentase ketuntasan pada materi struktur dan fungsi tumbuhan yaitu $16 \%$ siswa yang berada di atas ketuntasan minimal atau KKM $(\geq 75)$. Sementara persentase ketidaktuntasan siswa lebih besar yaitu $84 \%$. Perolehan nilai tertinggi siswa memiliki jarak yang cukup jauh dengan nilai terendah yang ditunjukan melalui nilai standar deviasi sebesar 52,6 dan rata-rata nilai siswa pada siklus I yaitu 52,6. Ringkasan hasil belajar kognitif ditampilkan pada Tabel 2.

Tabel 2. Hasil Belajar Kognitif

\begin{tabular}{lc}
\hline Deskripsi Hasil Belajar Kognitif & Nilai \\
\hline Nilai Maksimal & 91 \\
Nilai Minimal & 18 \\
Rerata & 52,6 \\
Standart Deviasi & 20,83 \\
Persentase Tuntas & $16 \%$ \\
Persentase Tidak Tuntas & $84 \%$ \\
\hline
\end{tabular}

Pengukuran sikap ilmiah siswa dilakukan melalui pengamatan yang meliputi sepuluh aspek pengamatan (tabel 3). Berdasarkan sepuluh indikator sikap ilmiah siswa yang diamati, diperoleh persentase ratarata sikap ilmiah siswa adalah $50 \%$. Ringkasan sikap ilmiah melalui pengamatan dapat dilihat pada Tabel 3.

Tabel 3. Sikap Ilmiah Siswa berdasarkan Pengamatan

\begin{tabular}{lcc}
\hline \multicolumn{1}{c}{ Deskripsi Indikator } & $\begin{array}{c}\text { Persentase } \\
\text { Capaian }\end{array}$ & Kategori \\
\hline Keinginan mendapatkan pengalaman baru & $56 \%$ & Baik \\
Mengajukan banyak pertanyaan & $50 \%$ & Cukup \\
Peserta didik aktif dalam kegiatan pembelajaran & $61 \%$ & Sangat Baik \\
Menyampaikan secara lisan fakta dan data sesuai & $49 \%$ & Cukup \\
dengan apa yang ditemukan & & \\
Menuliskan fakta dan data yang ditemukan & $52 \%$ & Cukup \\
Melakukan refleksi kegiatan yang telah dilakukan & $42 \%$ & Kurang \\
Menyampaikan perbedaan pendapat & $43 \%$ & Kurang \\
Berada dalam kelompok & $46 \%$ & Cukup \\
Menyelesaikan tugas pada waktunya & $56 \%$ & Baik \\
Berkompromi & $42 \%$ & Kurang \\
Rata-rata persentase ketuntasan & $50 \%$ & Cukup \\
\hline
\end{tabular}

Berdasarkan perolehan sikap ilmiah

siswa berdasarkan angket respon siswa diperoleh persentase nilai tertinggi pada kategori cukup yaitu 48\%. Sementara perolehan kategori kurang dan tidak baik memiliki akumulasi persentase 24\%. Ringkasan sikap ilmiah melalui angket dapat dilihat pada Tabel

4. 
Tabel 4. Sikap Ilmiah Siswa Berdasarkan Angket

\begin{tabular}{|c|c|c|}
\hline Kategori & $\begin{array}{c}\text { Jumlah } \\
\text { Siswa }\end{array}$ & Persentase \\
\hline Sangat & 1 & $4 \%$ \\
\hline Baik & & \\
\hline Baik & 6 & $24 \%$ \\
\hline Cukup & 12 & $48 \%$ \\
\hline Kurang & 5 & $20 \%$ \\
\hline Tidak Baik & 1 & $4 \%$ \\
\hline
\end{tabular}

keterlaksanaan pembelajaran berdasarkan lembar observasi di dapatkkan skor keterlaksanaan pembelajaran sebesar $65 \%$ pada pertemuan 1 dan $57 \%$ pada pertemuan 2 . Hasil dapat dilihat pada Gambar 1.

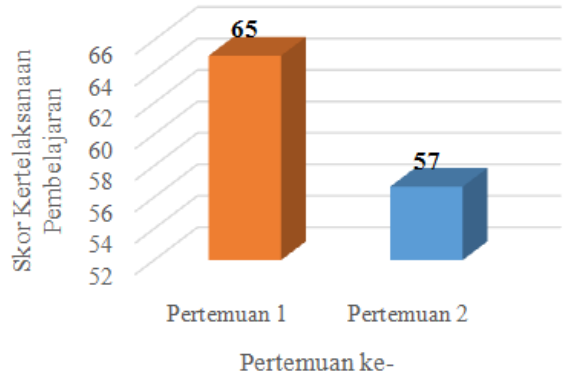

Gambar 1. Histogram Keterlaksanaan Model Bounded Inquiry Lab berbantuan Macromedia Flash

\section{Siklus II}

Tahap perencanaan kegiatan untuk siklus dua kurang lebihnya sama halnya yang dilakukan siklus I yaitu merancang silabus dan RPP yang akan digunakan untuk matetri siklus II, kemudian untuk lembar observasi siswa meliputi sikap ilmiah dan keterlaksanaan model pembelajaran sama seperti lembar siklus I, kemudian menyiapkan macromedia flash yang berisi materi pembelajaran struktur dan fungsi tumbuhan, untuk evaluasi siswa menggunakan pre test dan post test selama proses pembelajaran dan menyiapkan alat dan bahan yang digunakan untuk pembelajaran.

Tahap tindakan pada siklus II pertemuan pertama guru membuka pelajaran dengan memberi salam dan melakukan absensi kemudian sebelum memulai pembelajaran mengenai jaringan penyusun tumbuhan, siswa diingatkan tentang materi organ tumbuhan yang telah dipelajari pada pertemuan sebelumnya pada siklus I dan guru memberikan apresepsi dalam bentuk pertanyaan kepada siswa dan menyampaikan kepada siswa tujuan pembelajaran yang akan dicapai.

Kegiatan inti yang dilakukan guru yaitu menjelaskan jaringan meristem dan menjelaskan jaringan dewasa pada tumbuhan. Materi-materi ini disampaikan terlebih dahulu kepada siswa sebagai pemahaman konsep siswa dan selanjutnya diaplikasikan melalui kegiatan praktikum. Kemudian guru membentuk siswa menjadi 4 kelompok dan membagikan lembar kerja siswa mengamati struktur anatomi akar dan batang tumbuhan dengan cara kerjanya yang pertama mengamati bentuk akar dan batang kecambah kacang hijau dan kecambah jagung, identifikasi, terkhusus untuk bagian akar saja, apakah akar termasuk dalam golongan akar tunggang atau akar serabut, buatlah sayatan melintang pada akar dan batang dari tumbuhan kacang hijau dan jagung menggunakan silet, letakkan sayatan akar dan sayatan batang pada kaca benda, kemudian tetesi dengan air, tutuplah kedua kaca benda tersebut dengan kaca penutup, amatilah kedua preparat yang telah dibuat menggunakan mikroskop dengan perbesaran 40 kali, dan bandingan antara jaringan pada organ akar kacang hijau dan jagung dan bandingkan antara jaringan juga jaringan pada organ batang kacang hijau dan jagung.

Untuk praktikum ini ditekankan mengidentifikasi jaringan epidermis, parenkim, jaringan pengangkut, jaringan penyokong yang spesifik pada masing-masing organ tumbuhan serta perbedaan strukruktur anatomi akar dan batang tumbuhan dikotil dan monokotil. Dan guru mendampingi dan membimbing masingmasing kelompok dalam mengerjakan praktikum dan dalam lembar kerja siswa tidak hanya pengamatan saja yang dilakukan akan tetapi terdapat pertanyaan-pertanyaan yang harus didiskusikan dengan teman kelompok.

Pada awal pertemuan dua, guru mengingatkan kembali pembahasan materi pada pertemuan sebelumnya dan praktikum yang sudah siswa lakukan kemudian siswa mempresentasikan hasil kerja praktikum yang dilakukan berkelompok pada pertemuan sebelumnya, guru merumuskan penjelasan untuk membimbing siswa mengemukakan informasi yang diperoleh dan guru menjelaskan materi pembelajaran ditambahkan penguatan tentang jaringan dewasa. Diakhir pembelajaran siswa diberikan soal post test untuk mengetahui kemampuan akhir siswa pada siklus II.

Tahap observasi siklus II dilakukan pada siswa menggunakan lembar observasi siswa untuk pengamatan terhadap proses tindakan dalam penelitian yang bertujuan mengetetahui bagaimana aktivitas siswa selama proses pembelajaran siswa 
menggunakan model bounded inquiry lab berbantuan macromedia flash. Untuk observasi pertemuan dua pada siklus II pembelajaran yang dilakukan sudah selesai karena penelitian tindakan kelas menggunakan dua siklus meliputi 4 tahapan. Pada pertemuan ini selama proses pembelajaran siswa menggunakan model bounded inquiry lab berbantuan macromedia flash sudah berjalan dengan optimal dan untuk model dan media pembelajaran sudah dilakukan dengan baik sesuai dengan pengamatan yang telah dilakukan.

Tahap refleksi pada siklus II untuk melihat hasil pembelajaran baik hasil pembelajaran secara kognitif dan sikap ilmiah siswa serta kekurangan pada proses pembelajaran yang sudah dilakukan dengan menggunakan model bounded inquiry lab berbantuan macromedia flash. Untuk hasil pembelajaran kognitif refleksinya terjadi penurunan secara hasil belajar dibandingan dengan siklus II akan tetapi terjadi peningkatan pada sikap ilmiahnya. Pada siklus II diperoleh hasil belajar seperti pada tabel 5 .

Tabel 5. Hasil Belajar Kognitif

\begin{tabular}{lc}
\multicolumn{1}{c}{ Deskripsi Hasil Belajar } & Nilai \\
Kognitif & \\
\hline Nilai Maksimal & 64 \\
Nilai Minimal & 3 \\
Rerata & 21,88 \\
\hline
\end{tabular}

\begin{tabular}{lc}
\hline Standar Deviasi & 15,80 \\
Persentase Tuntas & $0 \%$ \\
Persentase Tidak Tuntas & $100 \%$ \\
\hline
\end{tabular}

Pada siklus 2 di peroleh hasil belajar kognitif siswa dengan perolehan presentase ketuntasan yaitu $0 \%$ siswa yang melewati kriteria ketuntasan minimal atau KKM yaitu $\geq$ 75 sementara persentase ketidaktuntasan siswa lebih besar yaitu 100\%. Perolehan nilai tertinggi siswa memiliki jarak yang cukup jauh dengan nilai terendah yang ditunjukan melalui nilai standart deviasi sebesar 15,80 . Untuk nilai rata-rata siswa pada siklus II sebesar 21,88 yang berarti sangat jauh dibawah KKM yang sudah ditentukan yaitu $\geq 75$. Ringkasan hasil belajar kognitif ditampilkan pada tabel 4. Untuk penilaian sikap ilmiah siswa dilakukan dengan teknik observasi. Dari sepuluh indikator sikap ilmiah yang dimati oleh abserver. Hasil tersebut dapat dilihat pada tabel 2 dengan rata-rata persentase ketuntasan 60\%. Dan terjadi peningkatan $10 \%$ dibandingan dengan siklus I yang sudah dilakukan.

\begin{tabular}{lcc}
\multicolumn{3}{c}{ Tabel 6. Sikap Ilmiah Siswa Berdasarkan Pengamatan } \\
\hline Deskripsi Indikator & $\begin{array}{c}\text { Persentase } \\
\text { Capaian }\end{array}$ & Kategori \\
\hline Keinginan mendapatkan pengalaman baru & $67 \%$ & Baik \\
Mengajukan banyak pertanyaan & $62 \%$ & Cukup \\
Peserta didik aktif dalam kegiatan pembelajaran & $64 \%$ & Baik \\
Menyampaikan secara lisan fakta dan data sesuai & $55 \%$ & Kurang \\
dengan apa yang ditemukan & $63 \%$ & Cukup \\
Menuliskan fakta dan data yang ditemukan & $44 \%$ & Kurang \\
Melakukan refleksi kegiatan yang telah dilakukan & $54 \%$ & Kurang \\
Menyampaikan perbedaan pendapat & $64 \%$ & Baik \\
Berada dalam kelompok & $66 \%$ & Baik \\
Menyelesaikan tugas pada waktunya & $63 \%$ & Cukup \\
Berkompromi & $60 \%$ & Cukup \\
Rata-rata persentase ketuntasan & &
\end{tabular}

Berdasarkan perolehan nilai sikap ilmiah siswa berdasarkan angket terdapat kategori dari sangat baik sampai tidak baik. Dan di dapatkan hasil bahwa yang paling mendominasi adalah pada kategori cukup dengan persentase sebesar $44 \%$ dari 25 siswa dalam satu kelas. Hasil dapat dilihat pada tabel 7. 
Tabel 7. Sikap Ilmiah Siswa berdasarkan Angket

\begin{tabular}{lcc}
\hline \multicolumn{1}{c}{ Kategori } & Jumlah Siswa & Persentase \\
\hline Baik & 9 & $36 \%$ \\
Cukup & 11 & $44 \%$ \\
Kurang & 4 & $16 \%$ \\
Tidak Baik & 1 & $4 \%$ \\
\hline
\end{tabular}

Berdasarkan hasil perolehan keterlaksanaan pembelajaran siklus II berdasarkan observasi di dapatkan skor keterlaksanaan pembelajaran sebesar $77 \%$ pada pertemuan 1 dan $63 \%$ pada pertemuan ke 2 . Hasil dapat dilihat pada Gambar 2.

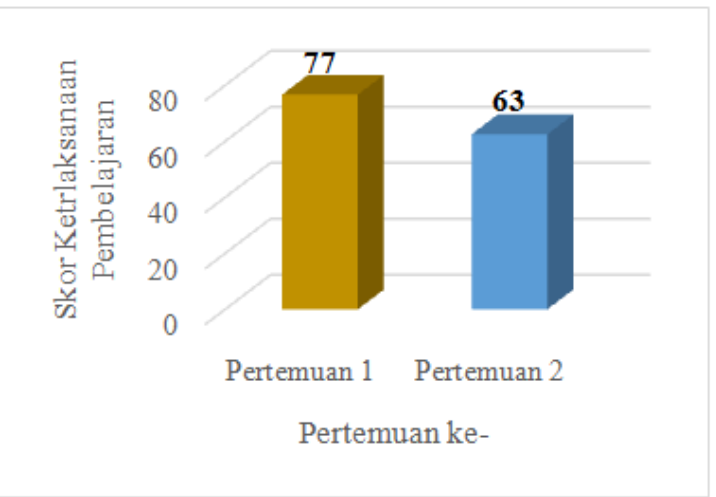

Gambar 2. Keterlaksanaan Model Pembelajaran pada Siklus II

\section{Pembahasan}

Berdasarkan hasil penelitian yang sudah di dapatkan pada siklus I dan siklus II pada penerapan model bounded inquiry lab berbantuan macromedia flash untuk meningkatkan hasil belajar dan sikap ilmiah dapat dijabarkan sebagi berikut:

\section{Penerapan model bounded inquiry lab berbantuan macromedia flash untuk meningkatkan hasil belajar}

Peningkatan hasil belajar kognitif siswa diukur menggunakan analisis gain score tes tertulis dari hasil pretest dan posttest. Berdasarkan hasil belajar kognitif siklus I persentase paling besar ada pada kategori sedang dengan jumlah $52 \%$ dan terjadi penurunan sejumlah $4 \%$ dari 25 siswa. Berdasarkan hasil belajar kognitif siklus II persentase diperoleh rata-rata $32 \%$ ada pada tiga ketegori yaitu sedang, rendah, terjadi penurunan dan terdapat juga tidak terjadi peningkatan dengan persentase $4 \%$.

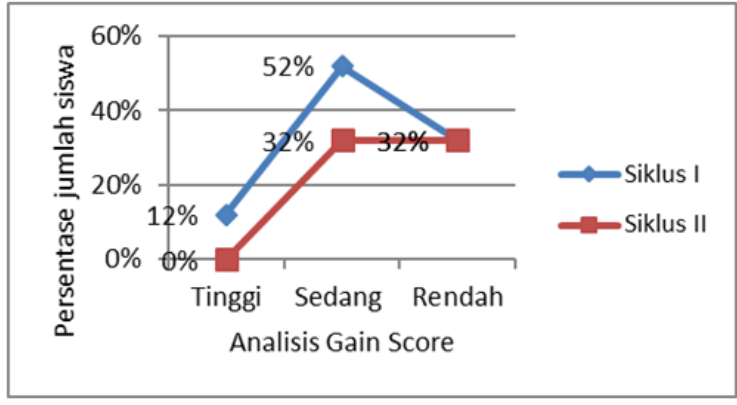

Gambar 3. Peningkatan hasil belajar berdasarkan Gain Score

Berdasarkan Gambar 3 dapat dilihat bahwa dari siklus I menuju ke siklus II hasil belajar kognitif mengalami penurunan atau tidak terjadi peningkatan dengan kriteria ketuntasan perolehan KKM yaitu $\geq 70 \%$. Berdasarkan hasil refleksi dengan guru, penurunan hasil belajar kognitif dari siklus I ke siklus II disebabkan karena siswa lebih suka belajar dengan mencatat. Hasil catatan yang dilakukan siswa akan dipelajari secara mandiri. Proses belajar siswa masih bergantung pada cara guru menyampaikan materi. Ketika siswa diajak untuk memahami konsep melalui praktikum, siswa masih cenderung pasif dalam mengerjakan tanggung jawab dikelompok.

Berdasarkan wawancara dengan lima orang siswa, diperoleh bahwa siswa masih belum berminat belajar IPA melalui aktivitas laboratorium. Siswa beranggapan bahwa aktivitas laboratorium mengurangi waktunya untuk memahami materi secara klasikal. Selain itu, berkurangnya jam belajar siswa secara mandiri banyak dipengaruhi oleh minat belajar siswa yang kurang untuk mata pelajaran IPA. Bahkan ketika siswa mengalami kesulitan di kelas, hanya ada beberapa siswa saja yang aktif bertanya. Selanjutnya sering ditemukan siswa yang menyepelekan tugas yang diberikan guru dan kurang persiapan dalam menghadapi tes kognitif secara tertulis.

\section{Penerapan model bounded inquiry lab berbantuan macromedia flash untuk meningkatkan sikap ilmiah siswa}

Peningkatan sikap ilmiah dari siklus I ke siklus II siswa diukur melalui pengamatan aktivitas berdasarkan aspek sikap ilmiah. Rerata peningkatan yang terjadi dari tiap aspek yaitu $10 \%$. Hal ini menunjukkan bahwa perbaikan yang dilakukan guru dan kolaborator untuk memodifikasi pelaksanaan model bounded inquiry lab berbasis macromedia flash dengan memberikan pendekatan individu serta 
kelompok pada saat praktikum. Selain itu, penampilan pada slide macromedia flash dimodifikasi dengan memberikan pertanyaan dan tayangan yang lebih bervariasi. Berdasarkan observasi keterlaksanaan pembelajaran, siswa terlihat lebih tertarik dan menumbuhkan rasa ingin tahu siswa. Pelaksanaan pembelajaran yang dilakukan oleh guru di dalam kelas menggunakan macromedia flash terlebih dahulu dengan tayangan video struktur dan fungsi tumbuhan sehingga sangat menarik siswa dan setelah itu siswa melakukan praktikum dengan model bounded inquiry lab. Pembelajaran yang mengadopsi tahapan bounded inquiry lab memberikan kesempatan leluasa untuk aktivitas di laboratorium melalui metode ilmiah sesuai dengan kemampuan berfikir dan tingkat pemahaman sains siswa (Johnson et al, 2006).

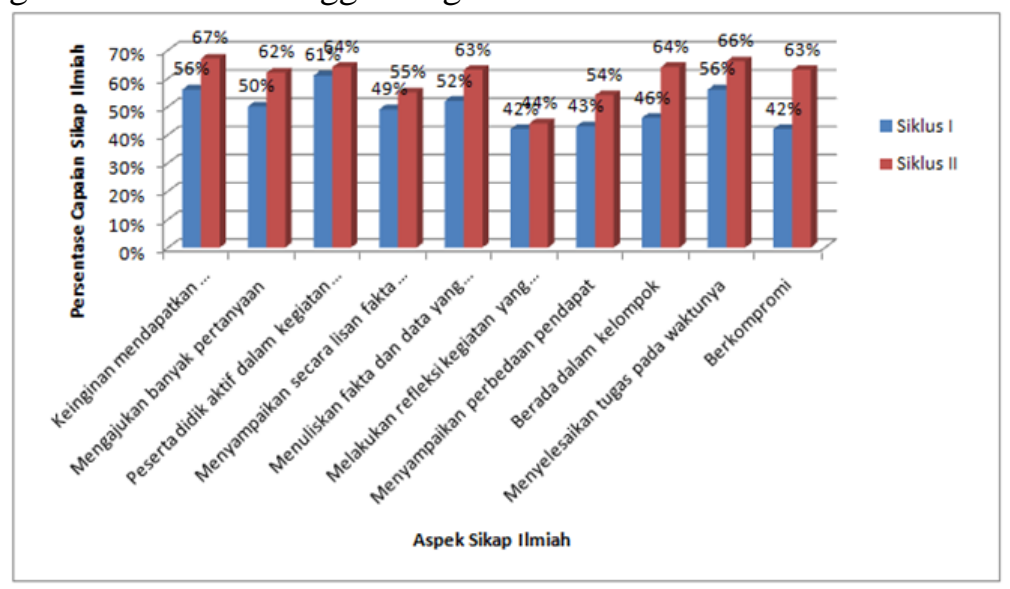

Gambar 4. Peningkatan Sikap Ilmiah Siswa antar Siklus

\section{Penerapan Model Bounded Inquiry Lab berbantuan Macromedia Flash}

Model pembelajaran bounded inqury lab sebenarnya dapat memfasilitasi siswa untuk dapat menyelidiki permasalahan dalam sains melalui aktivitas praktikum. Wenning (2007) menjelaskan bahwa model bounded inquiry lab memberikan kesempatan pada siswa untuk berproses serta mengaplikasikan berbagai konsep sains yang dipelajari di kelas. Namun dalam implementasi pembelajaran dari siklus I dan siklus II, perbaikan yang dilakukan dari proses penyajian pengajaran masih belum memberikan dampak peningkatan yang diharapkan terhadap hasil belajar kognitif. Berdasarkan hasil refleksi di siklus I dan siklus II, siswa butuh penyiapan yang matang dalam mengikuti model bounded inquiry lab. Artinya penyiapan pemahaman siswa dalam aktivitas laboratorium dapat dilakukan dengan membiasakan siswa untuk beraktivitas dan menemukan konsep berbasis kepada penemuan dan praktikum.

Di sisi yang lain, jika ditinjau dari peningkatan sikap ilmiah, penggunaan model bounded inquiry lab berbantuan macromedia flash memberikan dampak peningkatan dari siklus I ke siklus II. Hal ini terlihat dari aktivitas beberapa siswa dalam pembelajaran yang aktif dalam memberikan gagasan/pendapat, membangkitkan rasa ingin tahu, dan bersifat terbuka dengan teman kelompok. Liliawati et al (2014) menjelaskan bahwa model bounded inquiry lab dapat mendorong peserta didik untuk aktif dalam pembelajaran dalam menemukan konsep sehingga dapat mengkontruksi pengetahuan sendiri dan mengkontruksi kemampuan konsep dan proses itu membangkitkan rasa ingin tahu siswa dan dalam bekerja siswa memiliki sikap yang terbuka dengan teman kelompoknya.

\section{Simpulan dan Saran}

Simpulan

Penerapan Model Bounded Inquiry Lab berbantuan macromedia flash untuk meningkatkan hasil belajar berdasarkan hasil siklus I dan siklus II mengalami penurunan atau tidak terjadi peningkatan dengan kriteria ketuntasan perolehan KKM yaitu $\geq 70 \%$. Penerapan model bounded inquiry lab berbantuan macromedia flash untuk meningkatkan sikap ilmiah siswa dapat meningkatkan sikap ilmiah siswa dengan ratarata peningkatan setiap aspek sikap ilmiah sebesar $10 \%$ dengan total rerata keseluruhan indikator yaitu $60 \%$.

Saran 
Penelitian ini dapat dilanjutkan atau dikembangkan kembali dengan mengembangkan penerapan model bounded inquiry lab berbantuan macromedia flash dipadukan dengan media atau model pembelajaran yang menarik lainnya agar kemampuan kognitif khususnya dapat meningkat secara optimal

\section{Daftar Pustaka}

Arikunto. (2006). Prosedur Penelitian Suatu Pendekatan Praktek. Jakarta : PT. Rineka Cipta.

Arsyad, Azhar. (2004). Media pendidikan. Jakarta: Gramedia.

Azwar, Saifuddin. (1999). Reabilitas dan Validitas. Yogyakarta : Sigma Alpha.

Candra, D.T. (2007). Memilih Buku Pelajaran IPA. Diakses tanggal 27 Oktober 2018 dari http://pelangi.ditplp.go.id

Daryanto. (2011). Penelitian Tindakan Kelas dan Penelitian Tindakan Sekolah. Yogyakarta. Gava Media.

E. Mulyasa. Pengembangan Implementasi Kurikulum. (2013). Bandung: PT. Remaja Rosdakarya.

Handayani, Suciati \& Marjono. (2016). Peningkatan Keterampilan Proses Sains Pada Pembelajaran Biologi Melalui Penerapan Model Bounded Inquiry Lab. Jurnal Bioedukasi, 9(2): 49-54.

Hermita, R, Suciati, \& Rinanto, Y. (2016). Pengembangan Modul Berbasis Bounded Inquiry Laboratoty (Lab) Untuk Meningkatkan Literasi Sains Dimensi Proses Pada Materi Sistem Pencernaan Kelas XI. Jurnal Inquiry, 5(2):94-107.

Johnson, D., Levy, F., Karsai, I., and Stroud, K. (2006). Turning the Potential Liability of Large Enrollment Laboratory Science Courses Into an Asset. Journal of College Science Teaching. Diperoleh 14 Oktober 2014. Tennesse: Department of Biological Sciences at East Tennessee State University Johnson City.
Wenning. (2007). Assessing inquiry skills as a component of scientific literacy. J. Phys. Tchr. Educ. Online. Vol. 4 (2): 21-24.

Liliawati, W., Purwanto, Ramlan. T., Hidayat, R., Megawati, E., dan Puspitasari, F.T. (2014). Analisis Kemampuan Inquiry Siswa SMP, SMA dan SMK Dalam Penerapan Levels of Inquiry Pada Pembelajaran Fisika. Jurnal Pendidikan FMIPA Universitas Pendidikan Indonesia, 6(2).

Martiningsih, Meidini., R.P. Situmorang., dan Susanti, P.H. (2018). Hubungan Keterampilan Generik SAins dan Sikap Ilmiah melalui Model Inkuiri Ditinjau dari Domain Kognitif. Jurnal Pendidikan Sains Unimus, 6(1): 24-33.

Muchlas, S \& Hariyanto. (2011). Konsep dan Model Pendidikan Karakter. Bandung : Remaja Rosdakarya.

Sanjaya, R.W.K, Maridi, \& Suciati. (2017). Pengembangan Modul Berbasis Bounded Inquiry Lab Untuk Meningkatkan Literasi Sains Dimensi Konten Pada Materi Sistem Pencernaan Kelas XI. Jurnal Inquiry, 6(3): 1-16.

Arikunto, Suhardjono, dan Supardi. (2006). Peneilitian Tindakan Kelas. Jakarta: Bina Aksara.

Syafa. (2014). Karakteristik Proses Pembelajaran Kurikulum 2013. Dinamika Ilmu, 14(1).

Tursinawati. (2013). Analisis Kemunculan Sikap Ilmiah Siswa Dalam Pelaksanaan Percobaan Pada Pembelajaran IPA Di SDN Kota Banda Aceh. Jurnal Pionir, 1. (1). 